of the Norris-LaGuardia Act and of the conditions prompting its adoption, ${ }^{22}$ lends support to the current view that Mr. Justice Frankfurter's opinion is but an anomalous attempt to whitewash all union undertakings as long as they are conducted in a gentlemanly fashion. ${ }^{23}$ It is, therefore, possible that the Court will ultimately treat this opinion as mere dictum and adopt Mr. Chief Justice Stone's concurring opinion as the proper rationale. ${ }^{24}$ If the Chief Justice could then be prevailed upon to put his "substantiality" test to work, the Court could, without loss of face, decide against the union in the newly-brought case we have been considering. ${ }^{25}$

\title{
SECRET LIENS AND THE CHANDLER ACT
}

Decisions interpreting the preference provisions of the Bankruptcy Act of I 898 reveal the presence of two conflicting policies; ${ }^{\mathrm{T}}$ Congress and the Supreme Court appear to have chosen opposite sides in the controversy between the general creditors and particular creditors who claim the benefit of secret liens. Behind legal phraseology is concealed a balancing of the important economic interests. Interpretations by the Court of successive amendments to Section $60^{2}$

22 The desire for procedural reform to curb the use of injunctions appears to have been the sole motive behind the statute. Both foes and supporters of the bill agreed that it was not in any way meant to widen civil and criminal immunities. 75 Cong. Rec. 5462 et seq. (1932). Mr. Justice, then Professor, Frankfurter himself asserted then that the Act "explicitly applies only to the authority of United States courts 'to issue any restraining order or injunction.' All other remedies in federal courts and all remedies in state courts remain available." Frankfurter and Greene, The Labor Injunction 220 (1930).

${ }^{23}$ Steffen, Labor Activities in Restraint of Trade: The Hutcheson Case, 36 IIl. L. Rev. I (I94I); Gregory, The New Sherman-Clayton-Norris-LaGuardia Act, 8 Univ. Chi. I. Rev. 503 (I94I); see Landis, The Apex Case-Addendum, 26 Cornell L. Q. 212A (I94I).

24 This is a very real possibility in view of the somewhat analogous manner in which the doctrine of picketing as free speech enunciated in Thornhill v. Alabama, 310 U.S. 88 (I940), has been drastically limited by the case of Carpenter and Joiners Union of America, Local No. $2{ }^{2} 3$ v. Ritter's Cafe, $3 \times 5$ U.S. 722 (I942). But the prompt affirmance of the Hutcheson case in three cases indicates that perhaps the time for overhauling has not yet arrived. United States v. Building and Construction Trades Council of New Orleans, 4 C.C.H. Lab. Cas. $\prod_{51, I I 8}$ (I94I), aff'd $3^{\mathrm{I} 3}$ U.S. 539 (r94I); United States v. United Brotherhood of Carpenters and Joiners of America, 4 C.C.H. Lab. Cas. I5x,II8 (r94r), aff'd $3^{1} 3$ U.S. 539 (I94I); United States v. Carrazzo, 37 F. Supp. Igx (Ill. x94r), aff'd sub nom. Int'I Hod Carriers' and Com-

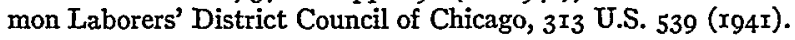

${ }_{25}$ It should be noted that most of the theatres are already organized by a rival union; but this cannot be expected to influence the decision, since a jurisdictional dispute has already been presented to the Court in the Hutcheson case and appeared to disturb none of the judges. See Gregory, Union Peacetime Restraints in Collective Bargaining, Io Univ. Chi. L. Rev, I88 ff. (I943), for proposed legislative solutions to the growing problem of internecine conflict.

I Britton, Equitable Liens-A Tentative Analysis of the Problem, 8 N.C.L. Rev. 388 (x930); Validity of Liens Against a Trustee in Bankruptcy, 34 Yale L.J. 89I (1925); Voidability in Bankruptcy of Transfers Recorded within the Four Months Period, 44 Yale L.J. Iog (r934).

2 Chandler Act $\S 60(a), 52$ Stat. 869 (I938), II U.S.C.A. $\S 96$ (a) (Supp. r942): "A preference is a transfer, as defined in this Act, of any of the property of a debtor to or for 
have repeatedly frustrated what authorities believe was Congressional intent. ${ }^{3}$ The extraordinary role which bankruptcy plays in a competitive structure built around traditional property rights makes the divergence of view understandable. In the interest of equal distribution of the assets of the bankrupt, legislative regulation halts the race of the diligent to secure priority through common law title concepts. ${ }^{4}$ The common law retreats reluctantly and cautiously, and, though we are able quite clearly to see major policy outlines, comparatively minor variations in the facts give rise to serious difficulties.

That the Chandler Act has changed the law of preferences is conceded. The precise nature of the change is in dispute. Typical situations will illustrate the areas of certainty and uncertainty. A creditor of the bankrupt claims status as a secured creditor because of a mortgage obtained by him to secure a thenexisting debt. The mortgage was later recorded within four months of bankruptcy. Before the Chandler Act, it was held that this did not constitute a voidable preference..$^{5}$ Under the Chandler Act, the transfer is "deemed to have been made at the time when it became so far perfected that no bona-fide purchaser from the debtor and no creditor could thereafter have acquired any rights in the property so transferred superior ...." to those of the mortgagee. Since the original mortgage was clearly a transfer "for or on account of an antecedent debt," it is a preference if the other elements are present. This interpretation is clearly sound and is illustrated by a recent decision. ${ }^{7}$ In this case, to secure a then-existing debt, a creditor obtained and recorded a mortgage with an afteracquired property clause. The mortgage was executed and recorded ten months before bankruptcy. Within four months of the filing of the petition, and at a time when the debtor was insolvent, the mortgagee took possession of afteracquired property. The court found that under the law of the state until the

the benefit of a creditor for or on account of an antecedent debt, made or suffered by such debtor while insolvent and within four months before the filing by or against him of the petition in bankruptcy .... the effect of which transfer will be to enable such creditor to obtain a greater percentage of his debt than some other creditor of the same class. For the purpose of subdivisions $a$ and $b$ of this section, a transfer shall be deemed to have been made at the time when it became so far perfected that no bona-fide purchaser from the debtor and no creditors could thereafter have acquired any rights in the property so transferred superior to the rights of the transferee therein, and, if such transfer is not so far perfected prior to the filing of the petition in bankruptcy .... it shall be deemed to have been made immediately before bankruptcy."

3 McLaughlin, Aspects of the Chandler Bill to Amend the Bankruptcy Act, 4 Univ. Chi. L. Rev. 369, 388-95 (1937); McLaughlin, Amendment of the Bankruptcy Act, 40 Harv. L. Rev. 34I, 374-9I (I927); Mulder, Ambiguities in the Chandler Act, 89 U. of Pa. L. Rev. 10, 22-26 (1940); 3 Collier, Bankruptcy I60.05-.06 (I4th ed. 194r).

4 For the general theories underlying preferences in bankruptcy, see 3 Collier, Bankruptcy T60.0I (I4th ed. I94I).

5 Carey v. Donohue, 240 U.S. 430 (I9I6).

${ }^{\circ}$ Chandler Act $\S 60(a), 5^{2}$ Stat. 869 (1938), I I U.S.C.A. $\S 96(a)$ (Supp. 1942).

7 In re Markert, 45 F. Supp. 66r (Mass. I942). 
mortgagee took possession, a bona fide purchaser or an attaching creditor could have acquired rights in the property superior to those of the mortgagee. Until possession was obtained, the security was not "so far perfected" and therefore the transfer, within the meaning of the Act, occurred when possession was taken. Since this was within four months of the filing of the petition and since the mortgage was given to secure an antecedent debt, the transfer constituted a preference. If the mortgagee had never obtained possession, or, in the case of an unrecorded mortgage, had not recorded at all, the transfer, not having been perfected prior to the petition, would be "deemed to have been made immediately before bankruptcy," and, the other elements being present, would be a preference. This interpretation appears to be well established. ${ }^{8}$

Despite its general objective of equality among creditors, the Bankruptcy Act protects the claims of those who by their diligence have promptly secured their claims by legally recognized liens good not only between the parties but against the world at large. But fairness to unsecured creditors who may have loaned or given forbearance in reliance on the debtor's appearance of prosperity requires that lienors give adequate notice of their claims in a recognized manner, such as recording or taking possession. Moreover, the Act prevents the depletion of the bankrupt's estate by "diligent" creditors within the four months period, if such depletion occurs while the debtor is insolvent and the creditors know of the insolvency. 9 The policy against disappointing reasonable expectations is incorporated into the Act through reference to the state laws; equality is promoted by setting aside preferences made within the four months' period.

A small change in the situation first discussed may lead to a strikingly different result. If a mortgage is executed more than four months before bankruptcy to secure a debt which is created simultaneously and later the mortgage is recorded within the four months period, a court may hold that there is no preference. This was true before the Chandler Act. ${ }^{\text {xo }}$ Similarly, if the bankrupt gives the claimant a bill of sale conveying property to secure a debt created simultaneously, and it is subsequently recorded within four months of filing of the petition, it has been held in Adams v. City Bank \& Trust Co. of Macon, Ga..$^{\mathrm{II}}$ that this is no preference under the Chandler Act, because it is not a transfer made "for or on account of an antecedent debt." It is said that here is no diminution of the estate, since the original unperfected conveyance was made for adequate present consideration.

${ }^{8}$ In re Talbot Canning Corp., 35 F. Supp. 680 (Md. I940), noted in 40 Mich. L. Rev. ro5 ( $x_{94} \mathrm{I}$ ), remanded for further findings of fact, In re Talbot Canning Corp., 39 F. Supp. 858 (Md. r94I), rev'd on the other findings of fact sub nom. Associated Seed Growers v. Geib, I25 F. (2d) 683 (C.C.A. 4th I942); In re Seim Const. Co., 37 F. Supp. 855 (Md. I94I).

9 Equitable Liens and Pledges: A Study in Security and Bankruptcy Law, 37 Col. L. Rev. 62r, 627 (I937); 4I Col. L. Rev. 5r2, 515 (r94r).

so Martin v. Commercial Nat'l Bank, 245 U.S. $5^{13}$ (19r8).

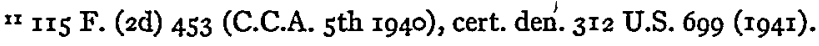


This point of view has been adversely criticized..$^{22}$ If one considers only the four months period, the bankrupt's estate is diminished if the mortgage is perfected by the tardy recording. There is no less a diminution than when the security was, given for a pre-existing debt. The same kind of reliance, or danger of reliance, is present, and expectations may be equally frustrated. In both cases the real diminution of the debtor's estate occurs when the creditor is made secure against other creditors, and that occurs within the four months period..$^{13}$ Creditors who rely on appearances while the mortgage is a secret lien will find little solace in the fact that at the time the mortgage was executed the debtor received "present consideration." Such "adequate value" does not reduce the danger of injury from the secret lien. Indeed, since it adds to the estate, it may increase the danger that credit may be given in reliance on the appearances. Recording acts do not treat these two situations differently; the difference is recognized apart from the Bankruptcy Act, and it is difficult to see why a distinction should be drawn for the purposes of the Chandler Act.

The technical difficulty in interpretation arises from the ambiguity of the phrase "antecedent debt." What is the point of time with reference to which it is to be judged whether the debt secured was or was not "antecedent"? The words appear in the Bankruptcy Act for the first time with the Chandler Act Amendments in 1938 . Prior to that time, it was held that any recording "related back" to the time of original mortgage. In I938 Congress reversed the fiction and declared that a transfer shall be deemed to have been made at the time when the security became "so far perfected" that no bona fide purchaser or no creditor could obtain superior rights in the property. If a debt existed before that time, it would seem that it is "antecedent" within the meaning of the Act: antecedent in the sense of existing before the time at which the transfer is deemed to have been made. Such an interpretation gives effect to the intent of Congress to strike down secret liens. ${ }^{14}$ The interpretation should not, as has been suggested, ${ }^{x}$ invalidate transactions where recording follows promptly. The Act may be interpreted to recognize as continuous a transaction lasting

12 For a criticism of the decision in the Adams case, see notes in $4 \mathrm{I}$ Col. L. Rev. 5 I2 (r94I); 36 Ill. L. Rev. 783 (1942); 29 Calif. L. Rev. 522 (r94I).

${ }^{3}$ Even if the unperfected conveyance was made within the four months period, but recorded later, there may be reliance on the part of some creditor, and the doctrine of Moore v. Bay, 284 U.S. 4 (I93 I) (that a claim void as against some but not all the creditors of the bankrupt may be avoided in toto by the trustee in bankruptcy, even though creditors generally benefit by the avoidance) could be extended to protect all; Friedman v. Sterling Refrigerator Co., IO4 F. (2d) 837 (C.C.A. 4th I939); Corley v. Cozart, II 5 F. (2d) rI9 (C.C.A. 5th r940); In re Leven, 42 F. Supp. 484 (Md. I94I).

${ }_{14}$ H.R. Rep. 1409, at 30, 75th Cong. Ist Sess. (1937); see also Weinstein, The Bankruptcy Law of 1938 I 20 (I938); 3 Collier, Bankruptcy (60.19-.29 (r4th ed. I94I); 2 Glenn, Fraudulent Conveyances $\$ \S 480-9 \circ$ (r940); McLaughlin, op. cit. supra note 3, at 392-93; Mulder, op. cit. supra note 3 , at 22-26.

${ }^{15}$ Neuhoff, Assignment of Accounts Receivable as Affected by the Chandler Act, 34 Ill. L. Rev. 538, 547 (1940). 
over a reasonably short period of time. As a practical matter, there is always an interval of time between the execution of the security and its recording. The problem of "continuous transactions" is not peculiar to the interpretation of the Bankruptcy Act. ${ }^{16}$

A recent case supports the arguments outlined above. Between January I9 and April 5, I940, the Corn Exchange Bank made several loans to the Quaker City Sheet Metal Company. On April I2, I940, a Mr. Dearden also made a loan to the same company. Concurrently with each loan and as collateral security for it, the company assigned contracts and accounts receivable. On April I8, I940, an involuntary petition in bankruptcy was filed against the debtor company. Neither the bank nor Dearden gave notice of the assignments to the account debtors, and the transactions occurred in a state where such notice is necessary to protect the assignee against a bona fide purchaser of the account. The court found that the security was never "so far perfected" and that the transfer must therefore be deemed to have been made immediately before bankruptcy. The court held that the time of the making of the transfer is the essential element in determining whether the debt secured was antecedent, and that since the debt existed before the assignments were deemed made, within the meaning of the Act, the transfers were "for or on account of an antecedent debt" and constituted voidable preferences since the assignees knew of the debtor's insolvency at that time. ${ }^{17}$

The court expressly rejected the reasoning in the Adams case. ${ }^{88}$ The short time interval between assignment and bankruptcy presents the problem in its most difficult setting. Had the assignments in the Quaker City case been made a day or two after the loan, but not as a part of one continuous transaction, the result reached would apparently not be questioned. This change of facts does not appear to present a sufficient basis for distinction, since in both cases we are concerned with striking down secret liens.

The decision of the court in the Quaker City case presents, in addition, problems peculiar to the assignment of accounts receivable. If the rule of the case prevails, it may greatly restrict the use of accounts receivable as security. Assignment of accounts is widespread, and is considered good business practice

16 For examples of hardships of this kind that may arise, see Friedman v. Sterling Refrigerator Co., 104 F. (2d) 837 (C.C.A. $4^{\text {th }}$ 1939); General Motors Acceptance Corporation v. Coller, ro6 F. (2d) 584 (C.C.A. 6 th r 939 ), cert. den. 309 U.S. 682 (1940). The case of In re E. H. Webb, 32 F. Supp. 3 (Tenn. 1940), in which the transaction took place without the four months period and the mortgage was recorded the next day which fell within the four months period, is an example of the type of situation that should be explained as a "continuous transaction" rather than on the basis used by the court. The case is criticized in $4 \mathrm{I}$ Col. L. Rev. 5I2, $5 \mathrm{I} 6 \mathrm{n}$. I9 (I94).

${ }^{17}$ In re Quaker City Sheet Metal Co., I29 F. (2d) 894 (C.C.A. 3d I942). For another situation in which an assignment can fail to be "so far perfected" see In re Markert, 45 F. Supp. 66I (Mass. 1942).

${ }^{18}$ Note II supra and accompanying text. 
by established lending agencies. Often such intangibles are the only type of security left available, and it is feared that unfavorable decisions in bankruptcy cases may discourage extension of credit.

Two general views are illustrated in the decisions regarding the validity as against subsequent assignees of assignments of accounts receivable. ${ }^{\mathrm{Ig}} \mathrm{The} \mathrm{Su}-$ preme Court has held 20 that of the two "equities," the prior in time prevails, and that view is followed in a minority of the states. ${ }^{2 x}$ The English view, ${ }^{22}$ followed in other states, is that the assignee first giving notice to the account debtor prevails. In some states the choice between these views apparently turns upon a number of circumstances. The court in the Quaker City case was in Pennsylvania, a state which has adopted the English view. One writer has suggested that the mere possibility of a second assignment which might render the assignee's title imperfect is so remote a contingency that the possible "estoppel" should not be held a qualification to his rights. ${ }^{23}$ It has been argued that he has prima facie title, which should be regarded as "so far perfected. ...." The same observation may be made, however, about an unrecorded mortgage, which is perfectly valid between the parties, and which can be defeated only by fraud, deceit, mistake-or bankruptcy. Congress in the Bankruptcy Act wrote a comprehensive definition of what constitutes a "transfer" which includes assignments as well as mortgages and other liens. ${ }^{25}$

When bankruptcy intervenes after an assignment of accounts in a state following the rule that of two assignments the prior in time prevails, an interesting problem is presented. There appear to be three exceptions to the prior-in-time rule. If the second "equity" is "stronger," it will prevail. ${ }^{26}$ This will occur I) when the second assignee, acting in good faith, obtains payment of the claim assigned; 2) when the second assignee reduces his claim to judgment in his own name; or 3 ) when the second assignee effects a novation with the account debtor, whereby the obligation in favor of the assignee is superseded by a new one running to himself. In case of bankruptcy after an assignment is made in a state

29 Hamilton, The Efiect of Section Sixty of the Bankruptcy Act upon Assignments of Accounts Receivable, 26 Va. L. Rev. I68, I7 $1-73$ (1939).

${ }^{20}$ Salem Trust Co. v. Manufacturers' Finance Co., 264 U.S. 182 (1924).

${ }^{2 x}$ Neuhoff, op. cit. supra note 15 , at 538 n. 4 .

22 The leading case is Dearle v. Hall, 3 Russ. I (Ch. I827), in which the second assignee inquired of the account debtor whether the account was assigned and hence could show actual reliance. Courts have extended this doctrine in some jurisdictions to mean that the first assignee to give notice prevails, regardless of reliance.

23 Hamilton, op. cit. supra note 19 , at 178 .

24 Hamilton, op. cit. supra note $\mathrm{rg}$, at $186-87$.

${ }^{25} 52$ Stat. 842(30) (r938), II U.S.C.A. \& I(30) (Supp. I942).

${ }^{25}$ I Bogert, Trusts and Trustees $\$ 195$, at 558-60 (x935); see Salem Trust Co. v. Manufacturers' Finance Co., 264 U.S. 182, I99 (1924). 
where such a rule prevails, can it be said that the assignment is "so far perfected" that no bona fide purchase and no creditor could have secured any rights in the property superior to those of the first assignee, if he has not protected himself against these possibilities?

Answering this question in the negative does not, as has been suggested elsewhere, "accomplish the abolition of the business of lending money on book accounts." ${ }_{27}$ The first assignee can protect himself. ${ }^{28}$ Notification to the account debtor should be sufficient. If a second assignee then attempted to obtain payment, to effect a novation, or to obtain a judgment, he would normally be resisted by the account debtor who merely would have to prove the first assignment. If no resistance is given, one may suspect collusion between the second assignee and the account debtor, in which event the second transaction would be defeated as not bona fide. If, in addition, the first assignee takes additional precautions, insisting upon the stamping of the assigned accounts on the books of the assignor, making the assignor the agent for collection and deposit only, providing for deposit in a special account not accessible to the assignor, and providing for segregation of goods returned, he will be able to protect himself in all states. ${ }^{29}$

This is not too much to ask. An outstanding assignment which is known only to the assignor and the first assignee may mislead those who deal with the assignor. The existence of a secret lien is not conducive to the informed bargains which are essential to a healthy pursuit of enlightened self-interest. It is true that the borrower may not want his customers to know that he is in a weak condition, since they might hesitate to rely on his ability to perform his contracts with them. It has been argued that to be useful such assignments must be secret, ${ }^{30}$ else by the infinite routes through which business men obtain information, the suspicion of general creditors will be aroused to the determent of business. But notice will not result in undeniable curtailment of credit, nor will it precipitate into premature bankruptcy the only temporarily embarrassed debtor. ${ }^{35}$ Notice will not force a debtor into bankruptcy if an informed and dis-

27 Hamilton, op. cit supra note I9, at 187 .

${ }^{28}$ This does not subject the assignee to too great a burden. However, the Bankruptcy Act should be amended to except transactions in conformity with the Uniform Trust Receipts Act, as trust receipt transactions perfectly in accord with that Act will never become "so far perfected" against a bona fide purchaser. Uniform Trust Receipts Act $\$$ 9(2)(a), 9 U.L.A. 662, 687 (I942); see note in 26 Cornell L. Q. 306 (I94I).

${ }^{29}$ Writers have suggested precautions which should be taken by assignees to prevent the "unfettered use" of accounts receivable condemned as precluding the effective creation of a lien in Benedict v. Ratner, 268 U.S. 353, 364-65 (r925); Brinck, Accounts Receivable as Collateral, II Wash. L. Rev. I34 (1936); Accounts Receivable as Collateral Security, 44 Yale L.J. 639,648 et seq. (1935).

${ }^{30}$ Accounts Receivable as Collateral Security, 44 Yale I.J. 639 (1935).

${ }^{3 x}$ Voidability in Bankruptcy of Transfers Recorded within the Four Months Period, 44 Yale L.J. rog, Irg (r934). 
interested money market decides he may safely be permitted to stay in business. It is suggested that banks and professional lenders using this security device know the "moral and financial situation" of the debtor. ${ }^{32}$ It has never been demonstrated, however, that the sagacity and business judgment of the users of this particular type of security is any better than that of other creditors, professional or otherwise. The judgment concerning whether a business is to be continued or not should be made by a well-informed and complete money market, and not by a part of that market composed of holders of secret liens. Another argument presented by those who think "notice would be ruinous" 33 is that accounts receivable are usually used to secure so-called "enabling" or "rescue" loans. The creditor is said to take only part of what he put into the estate during the last few months of insolvency, leaving others in the same position as if he had never existed. This overlooks the possibility that the general creditors may be in a worse position because of appearances of prosperity and resultant further loans, forebearance, or postponed bankruptcy.

${ }^{32}$ Neuhoff, op. cit. supra note 15 , at 548 .

${ }^{33}$ Accounts Receivable as Collateral Security, 44 Yale L.J. 639 (1935). 